\title{
Instrument to assess educational programs for parents of children with congenital heart disease undergoing cardiac surgery
}

\author{
Paola Pino Armijo, Magister ${ }^{a}$, Muriel Ramírez León, B.S. ${ }^{b}$ and \\ Cristian Clavería Rodríguez, M.D.
}

\begin{abstract}
Objective. To design and validate an instrument to assess the relevance of educational programs for parents of children with congenital heart disease (CHD) undergoing cardiac surgery. Material and method. In October 2011, an instrument was designed based on Kaufman's model and on the bibliography, and a survey was developed in the form of a checklist with 32 close-ended questions about received education and desired education, categorized into 5 items: educator, time, place, means, and content. The survey was reviewed by 4 academic professionals and 9 experts in the care of children with CHD, and the checklist was extended to include 42 close-ended questions and 5 open questions. The instrument was administered on the day before discharge to the parents of children with CHD undergoing cardiac surgery at the Department of Pediatrics between February and August 2013. The survey was self-administered by the first participants and administered by the investigator among the remaining participants. Results. Fifty-five children met inclusion criteria; a total of 60 parents took part in the study. Agreement was observed between received education and desired education, which was statistically significant only in terms of education provided by a cardiologist $(p=0.000, \mathrm{~K}=0.659)$ and in the hall ( $p=0.000, K=0.655)$. Statistically significant differences were observed between the 19 self-administered surveys and the 41 surveys administered by the investigator. Among the latter, a greater level of completion was observed for all items.

Conclusion. A validated instrument was developed to assess the relevance of educational programs for parents of children with CHD undergoing cardiac surgery. This survey should be administered by a health care provider for a better understanding of information.

Key words: surveys and questionnaires, training program, parents, congenital heart disease.
\end{abstract}

http:/ / dx.doi.org/10.5546/ aap.2017.eng.439

Paola Pino Armijo,

Magister:

ppinoa@med.puc.cl

Funding:

None.

Conflict of interest: None.

Received: 10-4-2016

Accepted: 3-31-2017
To cite: Pino Armijo P, Ramírez León M, Clavería
Rodríguez C. Instrument to assess educational programs for parents of children with congenital heart disease undergoing cardiac surgery. Arch Argent Pediatr 2017;115(5):439-445.

\section{INTRODUCTION}

At present, education about congenital heart disease (CHD), medical treatments, and cardiac surgery is provided by health care providers, generally in an incidental or informal manner. However, the bibliography shows that, to ensure patients' well-being following hospital discharge, it is critical for health care providers to plan relevant educational programs to make sure parents gain the minimum necessary knowledge about their child's heart disease, treatment, and measures to prevent complications. ${ }^{1}$

Based on Kaufman's hypothesis, for education to be relevant, it is necessary to assess educational needs and establish the difference between "received education" and "desired education" among users because once gaps in present educational programs are identified, more effective programs may be implemented, thus preventing users from failing to meet their educational needs with present programs. ${ }^{2}$ For this reason, the first step to plan educational programs is to assess educational needs and understand that, according to this model, they account for "a gap between reality and what the investigator considers should be." ${ }^{2}$

However, no publications have been found in the bibliography that studied validated instruments to assess the relevance of educational programs for parents of children with CHD.

The objective of this study was to design and validate an instrument to assess the relevance of educational programs for parents of children with CHD undergoing cardiac surgery. 


\section{MATERIAL AND METHOD}

The process to design and validate the instrument was conducted by the Department of Pediatrics of the UC CHRISTUS Clinical Hospital in the period between October 2011 and October 2013. It consisted of three stages: instrument design, content validation, and pilot testing.

\section{Instrument design}

According to Kaufman's "problem solving" model (1973), educational needs may be assessed based on feedback or sensed needs or by means of specific empirical data, using different methods of interviews and questionnaires. ${ }^{2}$ Instruments of choice should provide information that accounts for both polarities of "what is" and "what should be" to obtain information on results, not processes. ${ }^{2}$ To this end, techniques and means should be selected, developed or created to assess needs taking into consideration three potential dimensions: nature of disease, nature of users, and nature of educators. ${ }^{2}$ (Figure 1).

In this study, an instrument was developed based on Kaufman's model to assess the relevance of an educational program using specific empirical data and considering "received education" (what it was) and "desired education" (what it should have been), and thefive key elements found in system planning: educator, time, place, means, and content. ${ }^{2}$

The survey allowed to obtain data from study subjects, using a printed instrument aimed at collecting responses on the study problem; participants completed it themselves or had a survey taker do it. The advantages of this method for data collection included its relatively low cost and ease to collect, analyze, and interpret data. ${ }^{3}$

To collect information, close-ended questions with dichotomous options were used because they required less time and a lower level of skills for the survey taker, a minor effort for the surveyed participant, and simplified data tabulation, among other advantages. ${ }^{3}$

The instrument was developed based on a comprehensive bibliographic search that retrieved the elements currently recommended by international experts.

The search included the following databases: Medline/Pubmed, Lilacs, ProQuest, Cinhal, and Scielo, and was conducted between October 2011 and February 2012. Key words used were: knowledge, education, educational program, educational intervention, educational needs, parents, congenital heart disease, congenital cardiopathy. Thirty articles were selected for analysis that met the following inclusion criteria: original research and bibliographic reviews in Spanish, Portuguese, and English, and published up to 10 years ago.

Article analysis allowed to define four areas: nature of disease, nature of users, nature of educators worldwide, and the proposal of an educational program for parents of children with CHD based on the bibliography and on Kaufman's model. ${ }^{4}$ A survey was developed in the form of a checklist with 32 close-ended questions categorized into 5 items: educator, time, place, means, and content. Each question provided information that

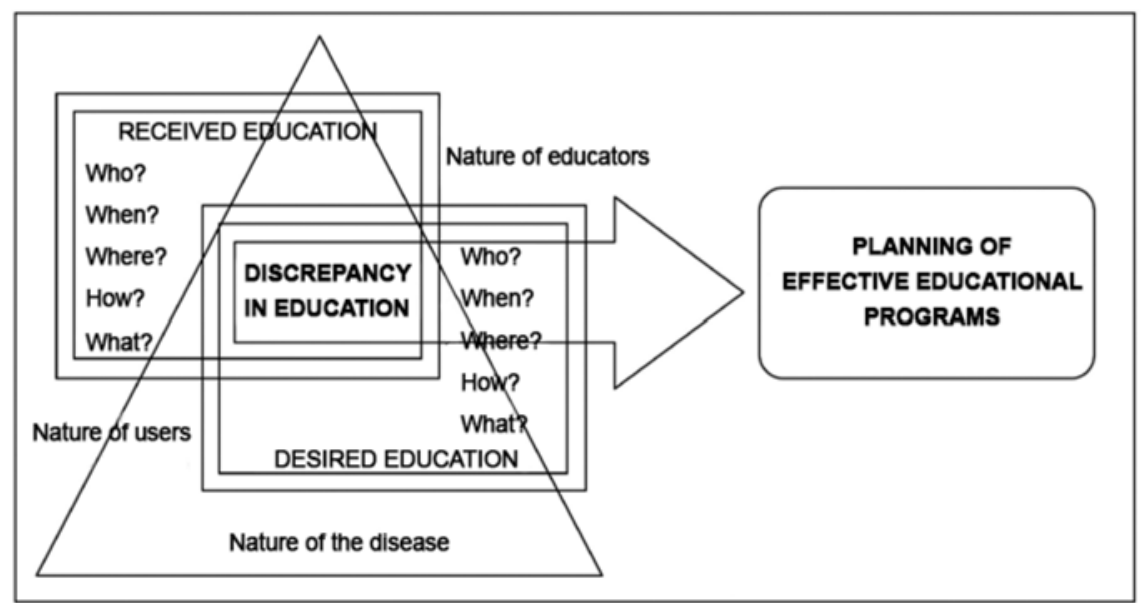


accounted for the outcome measures "received education" and "desired education" among users so as to establish agreement between them.

\section{Item 1. Educator:}

1) Treating physician; 2) Cardiologist and heart surgeon; 3) Nurse; 4) Other member of the health care team (nutritionist, physical therapist, educational psychologist, psychologist).

Item 2. Time:

5) Upon admission to the referral hospital; 6) During hospitalization; 7) Upon discharge or transfer to the referring hospital.

\section{Item 3. Place:}

8) In the child's room; 9) In a private room; 10) In the hall.

\section{Item 4. Means:}

11) Oral sessions; 12) Educational brochures; 13) Group workshops; 14) Indirect methods (videos, slides, hospital tours, Internet).

\section{Item 5. Content:}

Topic 1. Overview of heart disease: 15) Characteristics of the disease (course and prognosis); 16) Drug treatment (clinical use, dosing, adverse reactions, drug interactions); 17) Surgical treatment (type and number of surgeries required by the child).

Topic 2. Characteristics of cardiac surgery: 18) Preoperative assessment; 19) Type of anesthesia; 20) Potential consequences or complications of surgery; 21) Hospitalization in the intensive care unit (ICU); 22) Child's appearance after the surgery.

Topic 3. Care after cardiac surgery: 23) Routine care provided by the hospital; 24) Duration of intubation and monitoring; 25) Presence of invasive devices (catheters, tubes, drainages, pacemaker leads); 26) Skin and surgical wound care; 27) Opportunity to accompany their child and become involved in his/her care (feeding, hygiene, recreational activities).

Topic 4. Care after discharge: 28) Return to daily living activities; 29) Prevention and detection of growth problems; 30) Prevention and detection of nutritional complications; 31) Prevention and detection or respiratory complications; 32) Prevention and detection of cardiovascular complications.

\section{Content validation}

During the development of the project four academic professionals (two experts in research methodology, an expert in education methodology, and an expert in the specialized field) independently reviewed the survey.

In addition, the survey was reviewed by nine experts from different areas of care for children with CHD at a local level to establish if the checklist met its goals and whether questions were as clear as possible. ${ }^{3}$

The expert team consisted of a pediatric cardiologist, a pediatric heart surgeon, a pediatric intensivist, three nurses specialized in pediatric critical care, a nurse with a Master's Degree in Bioethics, an educational psychologist, and a child and adolescent psychologist. Each health care provider received a printed copy of the survey together with the guidelines and instructions for carrying out the assessment. They were asked to rate each question based on theoretical adequacy and clarity, indicating a score of 0 if the question did not meet assessment criteria or 1 if it met all. In addition, they were asked to suggest changes in a clear and accurate manner. Recommendations were introduced in the survey. Finally, the survey included 42 close-ended questions; an open question was added at the end of each item to gather feedback on received education and desired education not included in the checklist, and the item "content" was moved to the first place for a better understanding of information (Annex).

\section{Pilot testing}

The instrument was administered one day prior to discharge to the parents of children with CHD undergoing cardiac surgery at the Department of Pediatrics between February and August 2013 who met the following inclusion criteria: children undergoing corrective or palliative cardiac surgery, without respiratory support, not receiving vasoactive drugs, and hemodynamically stable, and whose parents were interested in participating and had signed the informed consent. Patients with a length of stay of less than 48 hours and those transferred to another department following recovery in the unit of pediatric critical patients (UPCP) were excluded.

In the first stage, the instrument was tested in the first three participants, in the presence of the principal investigator, to verify questions' quality in terms of understanding, individuals' willingness to answer, time required to complete it, and clarity of instructions. ${ }^{3}$

The rest of the surveys were administered by two of the study investigators who were proficient in the project; this way, all participants 
received the same instructions and explanations during the data collection period.

The survey was self-administered by the first 19 participants, who had no problems to complete it and had the chance to ask questions, as planned. However, the $20^{\text {th }}$ participant required constant support to complete the survey, so the instrument was administered by the principal investigator, and difficulties in understanding the information were evidenced. Observations were discussed among investigators, who decided that the remaining surveys should be administered by the investigator. In the end, 41 participants completed the survey administered by the investigator, which indicated that they felt more comfortable and willing to answer with this modality.

The SPSS statistical software, version 17.0, was used for data analysis. A Kappa statistic was calculated to analyze agreement between the outcome measures "received education" and "desired education"; agreement was considered significant if the $p$ value was $<0.05$ and the $K$ value was $>60$. In addition, a $\chi^{2}$ test was done to analyze differences between the 19 selfadministered surveys and the 41 administered by the investigator, considering that a $p$ value $<0.05$ was a significant difference.

This instrument does not require an analysis of psychometric properties to assess its reliability and validity nor an internal consistency analysis to assess homogeneity among items because it was designed to collect information on results, not processes, and it is not a measurement scale to obtain scores on the quality of received education. . $^{5,6}$

The study was approved by the Ethics Committee of the School of Nursing and of the School of Medicine of Pontificia Universidad Católica de Chile.

\section{RESULTS}

A total of 122 children with CHD underwent cardiac surgery. Of these, 55 met the inclusion criteria; a total of 60 parents took part in the study.

Patients were mostly boys $(52.7 \%)$, with a median age of 10 months (between 1 month old and 18 years old), referred from the public health sector $(81.8 \%)$. There were no differences in the type of heart disease $(52.7 \%$ had a simple heart disease, defined as a clinically relevant defect, whereas $47.3 \%$ had a complex heart disease, defined as a life-threatening defect) ${ }^{7}$ most patients underwent cardiac surgery for the first time (63\%).

Participating parents were mostly mothers $(81.7 \%)$, with an average age of 32.7 years (standard deviation [SD]: \pm 7.7 years) and an average level of completed education of 11.8 years (SD: \pm 2.8 years). There were no differences in terms of marital status ( $48.3 \%$ were single and $48.3 \%$ were married), number of children $(33.3 \%$ had one child; $25 \%$, two children; and $31.7 \%$, three or more), or their occupation ( $45 \%$ were employed and $40 \%$ were stay-at-home parents), and most lived in an urban community (82.8\%).

The instrument was administered before discharge, with a median of 1 day between the survey and actual hospital discharge (range: 0 and 37 days).

Agreement between the outcome measures "received education" and "desired education" among parents was analyzed using the Kappa statistic. A statistically significant agreement was observed only in the education provided by the cardiologist $(p=0.000, \mathrm{~K}=0.659)$ and in the hall ( $p=0.000, \mathrm{~K}=0.655)$. However, significant results were obtained, although agreement was weaker, in relation to education provided by the pediatrician and the nurse, upon admission to the UC Clinical Hospital and during hospitalization, and regarding certain contents, such as drug treatment, surgical treatment, type of anesthesia and potential complications, potential surgeryrelated risks, hospitalization in the UPCP, physical appearance of the child after the surgery, routine care provided by the hospital, length of stay in the UPCP (days), and presence of invasive devices (Table 1).

In addition, differences were evidenced in the answers provided by the parents who completed the 19 self-administered surveys and the 41 surveys administered by the investigator, analyzed using the $\chi^{2}$ test. Statistically significant differences were observed in questions corresponding to the 5 items for the outcome measure "received education" (Table 2) and in those corresponding to 3 items for the outcome measure "desired education" (Table 3). Besides, the rate of answers to open questions was compared between both groups; the group of parents who took the survey with the investigator provided more complete answers to all items (Table 4).

\section{DISCUSSION}

This study describes the process to design and validate an instrument aimed at assessing the 
relevance of educational programs for parents of children with CHD undergoing cardiac surgery. The instrument was strictly developed based on the minimum required information to ensure the well-being of these patients after discharge, and was reviewed by four independent academic professionals and nine experts and pilot-tested in 60 parents.

TABLE 1. Agreement between the outcome measures "received education" and "desired education" $(n=60)$

\begin{tabular}{|c|c|c|c|c|}
\hline ITEMS & $\%$ DOES RECEIVE & $\%$ DOES DESIRE & KAPPA & CI $(95 \%)$ \\
\hline \multicolumn{5}{|l|}{ EDUCATOR } \\
\hline Pediatrician* & $91.7 \%(55)$ & $98.3 \%(59)$ & $\mathrm{p}=0.001 \mathrm{~K}=0.314$ & -0.158 to 0.786 \\
\hline Cardiologist ${ }^{* *}$ & $96.7 \%(58)$ & $98.3 \%(59)$ & $\mathrm{p}=0.000 \mathrm{~K}=0.659$ & 0.036 to 1.282 \\
\hline Nurse $^{*}$ & $91.7 \%(55)$ & $96.7 \%(58)$ & $\mathrm{p}=0.030 \mathrm{~K}=0.250$ & -0.191 to 0.691 \\
\hline Nutritionist & $46.7 \%(28)$ & $96.7 \%(58)$ & $\mathrm{p}=0.923 \mathrm{~K}=-0.004$ & -0.090 to 0.082 \\
\hline Physical therapist & $78.3 \%(47)$ & $96.7 \%(58)$ & $\mathrm{p}=0.323 \mathrm{~K}=0.080$ & -0.134 to 0.294 \\
\hline Educational psychologist & $18.3 \%(11)$ & $88.3 \%(53)$ & $\mathrm{p}=0.768 \mathrm{~K}=0.013$ & -0.065 to 0.091 \\
\hline Psychologist & $20 \%(12)$ & $83.3 \%(50)$ & $\mathrm{p}=0.386 \mathrm{~K}=0.048$ & -0.044 to 0.140 \\
\hline \multicolumn{5}{|l|}{ TIME } \\
\hline $\begin{array}{l}\text { Upon admission to the UC Clinical Hospital } \\
\text { (lost-to-follow-up=1) }\end{array}$ & $96.6 \%(57)$ & $94.9 \%(56)$ & $\mathrm{p}=0.003 \mathrm{~K}=0.375$ & -0.182 to 0.932 \\
\hline During hospitalization* (lost-to-follow-up $=1$ ) & $96.6 \%(57)$ & $96.6 \%(57)$ & $\mathrm{p}=0.000 \mathrm{~K}=0.482$ & -0.131 to 1.095 \\
\hline $\begin{array}{l}\text { Upon discharge or transfer to the referring } \\
\text { hospital (lost-to-follow-up=1) }\end{array}$ & $39 \%(23)$ & $96.6 \%(57)$ & $p=0.745 K=-0.012$ & -0.090 to 0.066 \\
\hline \multicolumn{5}{|l|}{ PLACE } \\
\hline In the child's room (lost-to-follow-up=2) & $96.6 \%(56)$ & $98.3 \%(57)$ & $p=0.849 K=-0.024$ & -0.057 to 0.009 \\
\hline In a private room* (lost-to-follow-up $=2)$ & $19 \%(11)$ & $56.9 \%(33)$ & $\mathrm{p}=0.001 \mathrm{~K}=0.301$ & 0.136 to 0.466 \\
\hline In the hall ${ }^{* *}$ (lost-to-follow-up $\left.=2\right)$ & $29.3 \%(17)$ & $37.9 \%(22)$ & $\mathrm{p}=0.000 \mathrm{~K}=0.655$ & 0.453 to 0.857 \\
\hline \multicolumn{5}{|l|}{ MEANS } \\
\hline Oral information & $98.3 \%(59)$ & $96.7 \%(58)$ & $\mathrm{p}=0.851 \mathrm{~K}=-0.023$ & -0.054 to 0.008 \\
\hline Educational brochures & $31.7 \%(19)$ & $93.3 \%(56)$ & $\mathrm{p}=0.767 \mathrm{~K}=0.013$ & -0.071 to 0.097 \\
\hline Group workshops & $11.7 \%(7)$ & $78.3 \%(47)$ & $\mathrm{p}=0.139 \mathrm{~K}=0.070$ & 0.009 to 0.131 \\
\hline Indirect methods & $16.7 \%(10)$ & $86.7 \%(52)$ & $\mathrm{p}=0.734 \mathrm{~K}=0.015$ & -0.063 to 0.093 \\
\hline \multicolumn{5}{|l|}{ CONTENT } \\
\hline \multicolumn{5}{|l|}{ Overview of heart disease } \\
\hline Characteristics of the heart defect & $93.3 \%(56)$ & $98.3 \%(59)$ & $\mathrm{p}=0.788 \mathrm{~K}=0.027$ & -0.016 to 0.070 \\
\hline Cause of the congenital heart disease & $70 \%(42)$ & $98.3 \%(59)$ & $p=0.509 K=-0.033$ & -0.096 to 0.030 \\
\hline Prognosis of congenital heart disease & $70 \%(42)$ & $100 \%(60)$ & $\mathrm{p}=0.139 \mathrm{~K}=0.071$ & -0.062 to 0.204 \\
\hline Drug treatment ${ }^{*}$ & $75 \%(45)$ & $96.7 \%(58)$ & $\mathrm{p}=0.013 \mathrm{~K}=0.188$ & -0.039 to 0.415 \\
\hline Surgical treatment ${ }^{*}$ & $85 \%(51)$ & $100 \%(60)$ & $\mathrm{p}=0.024 \mathrm{~K}=0.156$ & -0.116 to 0.428 \\
\hline \multicolumn{5}{|l|}{ Characteristics of cardiac surgery } \\
\hline Preoperative assessment & $96.7 \%(58)$ & $96.7 \%(58)$ & $\mathrm{p}=0.789 \mathrm{~K}=-0.034$ & -0.067 to -0.001 \\
\hline Type of anesthesia and potential complications* & $68.3 \%(41)$ & $96.7 \%(58)$ & $\mathrm{p}=0.035 \mathrm{~K}=0.139$ & -0.037 to 0.315 \\
\hline Potential risks or complications of surgery* & $93.3 \%(56)$ & $98.3 \%(59)$ & $\mathrm{p}=0.000 \mathrm{~K}=0.384$ & -0.151 to 0.919 \\
\hline Hospitalization in the UPCP* & $90 \%(54)$ & $100 \%(60)$ & $\mathrm{p}=0.006 \mathrm{~K}=0.227$ & -0.145 to 0.599 \\
\hline $\begin{array}{l}\text { Physical appearance of the child after the surgery* } \\
\text { (lost-to-follow-up = 1) }\end{array}$ & $79.7 \%(47)$ & $96.6 \%(57)$ & $\mathrm{p}=0.004 \mathrm{~K}=0.242$ & 0.214 to 0.270 \\
\hline \multicolumn{5}{|l|}{ Care after cardiac surgery } \\
\hline Routine care provided by the department* & $93.3 \%(56)$ & $100 \%(60)$ & $\mathrm{p}=0.001 \mathrm{~K}=0.314$ & -0.158 to 0.786 \\
\hline Length of stay in the UPCP (days)* & $81.7 \%(49)$ & $100 \%(60)$ & $\mathrm{p}=0.044 \mathrm{~K}=0.127$ & -0.100 to 0.354 \\
\hline Presence of invasive devices* & $91.7 \%(55)$ & $100 \%(60)$ & $\mathrm{p}=0.002 \mathrm{~K}=0.265$ & -0.152 to 0.682 \\
\hline Skin and surgical wound care & $50 \%(30)$ & $100 \%(60)$ & $\mathrm{p}=0.329 \mathrm{~K}=0.031$ & -0.030 to 0.092 \\
\hline $\begin{array}{l}\text { Opportunity to accompany their child and } \\
\text { become involved in his/her care }\end{array}$ & $86.7 \%(52)$ & $96.7 \%(58)$ & $p=0.573 \mathrm{~K}=-0.056$ & -0.009 to 0.121 \\
\hline \multicolumn{5}{|l|}{ Care after discharge } \\
\hline Return to daily living activities & $35 \%(21)$ & $98.3 \%(59)$ & $p=0.169 K=-0.034$ & -0.101 to 0.033 \\
\hline Measures to prevent growth problems & $36.7 \%(22)$ & $98.3 \%(59)$ & $\mathrm{p}=0.443 \mathrm{~K}=0.019$ & -0.020 to 0.058 \\
\hline Measures to prevent nutritional problems & $31.7 \%(19)$ & $95 \%(57)$ & $\mathrm{p}=0.949 \mathrm{~K}=-0.003$ & -0.081 to 0.075 \\
\hline Measures to prevent respiratory conditions & $35 \%(21)$ & $93.3 \%(56)$ & $\mathrm{p}=0.664 \mathrm{~K}=0.021$ & -0.069 to 0.111 \\
\hline Measures to prevent cardiovascular conditions & $26.7 \%(16)$ & $98.3 \%(59)$ & $\mathrm{p}=0.094 \mathrm{~K}=-0.034$ & -0.101 to 0.033 \\
\hline
\end{tabular}

* Significant but weaker agreement $(\mathrm{p}<0.05$ and $\mathrm{K}<60)$.

** Statistically significant agreement $(\mathrm{p}<0.05$ and $\mathrm{K}>60)$.

CI: confidence interval; UPCP: unit of pediatric critical patients. 
The results of the pilot test showed agreement only in the education provided by one educator and in one place, therefore it was established that the current educational program was not relevant. However, an even more relevant finding in this stage was the great difference between results of the self-administered surveys and those administered by the investigator because of difficulties related to the amount and quality of data.

TABLE 2. Differences between self-administered surveys and those administered by the investigator in relation to the outcome measure "received education"

\begin{tabular}{|c|c|c|c|}
\hline RECEIVED EDUCATION & $\begin{array}{l}\% \text { SELF-ADMINISTERED } \\
(\mathbf{n}=19)\end{array}$ & $\begin{array}{c}\% \text { ADMINISTERED BY } \\
\text { THE INVESTIGATOR }(n=41)\end{array}$ & $\chi^{2}$ \\
\hline \multicolumn{4}{|l|}{ EDUCATOR } \\
\hline Nutritionist & $68.4 \%$ & $36.6 \%$ & $\mathrm{p}=0.021$ \\
\hline Physical therapist & $94.7 \%$ & $70.7 \%$ & $\mathrm{p}=0.036$ \\
\hline Educational psychologist & $36.8 \%$ & $9.8 \%$ & $\mathrm{p}=0.012$ \\
\hline \multicolumn{4}{|l|}{ TIME } \\
\hline Upon discharge or transfer to the referring hospital & $78.9 \%$ & $20 \%$ & $\mathrm{p}=0.000$ \\
\hline $\begin{array}{l}\text { PLACE } \\
\text { In the hall }\end{array}$ & $56.6 \%$ & $17.5 \%$ & $\mathrm{p}=0.003$ \\
\hline \multicolumn{4}{|l|}{ MEANS } \\
\hline Educational brochures & $57.9 \%$ & $19.5 \%$ & $\mathrm{p}=0.003$ \\
\hline Group workshops & $26.3 \%$ & $4.9 \%$ & $\mathrm{p}=0.028$ \\
\hline Indirect methods & $31.6 \%$ & $9.8 \%$ & $\mathrm{p}=0.035$ \\
\hline \multicolumn{4}{|l|}{ CONTENT } \\
\hline $\begin{array}{l}\text { Cause of the congenital heart disease } \\
\text { Care after cardiac surgery }\end{array}$ & $89.5 \%$ & $61 \%$ & $\mathrm{p}=0.025$ \\
\hline Skin and surgical wound care & $73.7 \%$ & $39 \%$ & $\mathrm{p}=0.012$ \\
\hline $\begin{array}{l}\text { Opportunity to accompany their child and } \\
\text { become involved in his / her care } \\
\text { Care after discharge }\end{array}$ & $100 \%$ & $80.5 \%$ & $\mathrm{p}=0.039$ \\
\hline Return to daily living activities & $68.4 \%$ & $19.5 \%$ & $\mathrm{p}=0.000$ \\
\hline Measures to prevent nutritional problems & $52.6 \%$ & $22 \%$ & $\mathrm{p}=0.017$ \\
\hline
\end{tabular}

TABLE 3. Differences between self-administered surveys and those administered by the investigator in relation to the outcome measure "desired education"

\begin{tabular}{|c|c|c|c|}
\hline DESIRED EDUCATION & $\begin{array}{l}\% \text { SELF-ADMINISTERED } \\
\qquad(\mathrm{n}=19)\end{array}$ & $\begin{array}{c}\% \text { ADMINISTERED BY } \\
\text { THE INVESTIGATOR }(n=41)\end{array}$ & $\chi^{2}$ \\
\hline \multicolumn{4}{|l|}{ TIME } \\
\hline Upon admission to the UC Clinical Hospital & $83.3 \%$ & $100 \%$ & $\mathrm{p}=0.025$ \\
\hline \multicolumn{4}{|l|}{ PLACE } \\
\hline In a private room & $94.4 \%$ & $40 \%$ & $\mathrm{p}=0.000$ \\
\hline In the hall & $83.3 \%$ & $17.5 \%$ & $\mathrm{p}=0.000$ \\
\hline \multicolumn{4}{|l|}{ CONTENT } \\
\hline \multicolumn{4}{|l|}{ Care after discharge } \\
\hline Measures to prevent nutritional problems & $84.2 \%$ & $100 \%$ & $\mathrm{p}=0.028$ \\
\hline
\end{tabular}

TABLE 4. Differences between self-administered surveys and those administered by the investigator in relation to open questions

\begin{tabular}{lcc}
\hline OPEN QUESTIONS & $\begin{array}{c}\text { \% OF ANSWERS IN THE } \\
\text { SELF-ADMINISTERED } \\
\text { SURVEYS (n= 19) }\end{array}$ & $\begin{array}{c}\text { \% OF ANSWERS IN THE SURVEYS } \\
\text { ADMINISTERED BY THE } \\
\text { INVESTIGATOR (n= 41) }\end{array}$ \\
\hline Other contents & $10.5 \%$ & $68 \%$ \\
Other health care providers & $10.5 \%$ & $36.5 \%$ \\
Other time & $0 \%$ & $12.2 \%$ \\
Other places & $0 \%$ & $17 \%$ \\
Other means & $0 \%$ & $22 \%$ \\
Specify the indirect methods you received & $10.5 \%$ & $4.9 \%$ \\
Specify the indirect methods you desire & $21 \%$ & $90.2 \%$ \\
\hline
\end{tabular}


Although initially this instrument was planned to be self-administered to maintain participants' anonymity and remove any bias introduced by the survey taker, ${ }^{3}$ the pilot test helped to establish the reality of this group of parents, who many times did not understand the information and preferred not to ask questions even though there was a health care provider willing to clear any doubts they had. For this reason, we suggest that the survey be administered by a trained survey taker because it makes it easier for participants to answer the questions and the data gathered is more complete, consistent, and easier to process. ${ }^{3}$

Users' understating of information is critical to ensure patients' well-being after discharge. ${ }^{1,8}$ In this context, we find the concept of "health literacy," a social determinant defined as the skill "to understand instructions, adopt or disregard health beliefs, and practice self-care to improve care results and reduce treatment costs." ${ }^{\prime \prime}$ This concept becomes particularly relevant in pediatrics because health-related action outcomes are strongly associated with their parents' health literacy, who are completely responsible for their care at home once they are discharged.

In this group, health literacy poses a major challenge for the health team because these patients are referred from hospitals from different Chilean regions and therefore users have different education backgrounds. Although most participants come from the public health sector, have completed their education, are employed, and live in urban areas, there is a group of parents who have not completed their education, are stayat-home parents, and live in rural areas, and there is even a small group who comes from the private health sector, have a higher level of education and, many times, ask to include their nanny in the educational program sessions.

Educational interventions aimed at parents and children with CHD should provide a higher level of understanding of this disease's nature, treatment, and potential complications, which will certainly have an impact on patients' followup, with a reduction in morbidity and mortality in this high-risk group. ${ }^{8,10}$ This way, health care teams should use different strategies to convey information in a comprehensible manner to each user, also taking into account their specific characteristics so that they understand their children's CHD, thus favoring home-based care practices, especially in relation to treatment adherence and the prevention of risk behaviors. ${ }^{8-12}$

\section{CONCLUSION}

A validated instrument was developed to assess the relevance of educational programs for parents of children with CHD undergoing cardiac surgery. This survey should be administered by a health care provider for a better understanding of information among users.

\section{Acknowledgments}

We would like to thank the academic professionals who assisted us during the project preparation: Lilian Ferrer L., M.D., Yerko Molina M., Magister, Patricia Masalán A., Magister, and Olga Garrido V., Magister.

\section{REFERENCES}

1. Cheuk D, Wong S, Choi Y, et al. Parents' understanding of their child's congenital heart disease. Heart 2004;90(4): 435-9.

2. Kaufman R. Determinación de las necesidades educativas. In Kaufman R. Planificación de Sistemas Educativos: Ideas Básicas Concretas. 2.da ed. México: Trillas; 1973.Pages.41-67.

3. Pineda E, Alvarado E. Métodos, técnicas e instrumentos de investigación. En Pineda E, Alvarado E. Metodología de la Investigación. 3.ra ed. Washington DC: Organización Panamericana de la Salud; 2008.Pages143-68.

4. Pino Armijo P, Valdés Valenzuela CG, Fajuri Moyano P, et al. Propuesta de un programa educativo para padres de niños con cardiopatías congénitas. Arch Argent Pediatr 2014;112(5):451-6.

5. Campo-Arias A, Oviedo HC. Propiedades Psicométricas de una Escala: la Consistencia Interna. Rev SaludPública 2008;10(5):831-9.

6. Martín Arribas MC. Diseño y validación de cuestionarios. Matronas Prof 2004;5(17):23-9.

7. Chile. Ministerio de Salud. Guía Clínica: Cardiopatías Congénitas Operables en menores de 15 años. Santiago: MINSAL; 2010. [Accessed on: February $3^{\text {rd }}, 2016$ ]. Available at: http: / / web.minsal.cl/portal/url/item/720bfefe91e0d 2ede04001011f010ff2.pdf.

8. Daily J, FitzGerald M, Downing K, et al. Important knowledge for parents of children with heart disease: parent, nurse, and physician views. Cardiol Young 2016;26(1):61-9.

9. Piette J. Literacidad en Salud. Medwave 2009;9(5):e3921.

10. Ni Z, Chao Y, Xue X. An empowerment health education program for children undergoing surgery for congenital heart diseases. J Child Health Care 2016;20(3):354-64.

11. Staveski SL, Zhelva B, Paul R, et al. Pediatric cardiac surgery Parent Education Discharge Instruction (PEDI) program: a pilot study. World J Pediatr Congenit Heart Surg 2015;6(1):18-25.

12. Jackson AC, Liang RP, Frydenberg E, et al. Parent education programmes for special health care needs children: a systematic review. J Clin Nurs 2016;25(11-12):1528-47. 


\section{ANNEX}

Instrument to assess the relevance of an educational program

Read each question carefully and mark with an "X" the answer that best identifies you taking into account the education received by you during your child's hospitalization and the desired education.

\section{ITEM I: CONTENT}

TOPIC 1: Overview of heart disease

a) Characteristics of the heart defect:

Yes $\square$ No

Do you wish you had received information about this content?

Yes $\square$ No $\square$

b)Cause of the congenital heart disease:

Yes $\square$ No $\square$

Do you wish you had received information about this content?

Yes $\square$ No $\square$

c)Prognosis of the congenital heart disease:

Yes $\square$ No $\square$

Do you wish you had received information about this content?

Yes $\square$ No

d)Drug treatment (clinical use, dosing, adverse reactions, drug interactions):

Yes $\square$ No

Do you wish you had received information about this content? Yes $\square$ No $\square$

e) Surgical treatment (type and number of heart surgeries that your child may require):

Yes $\square$ No $\square$

Do you wish you had received information about this content?

Yes $\square$ No

TOPIC 2: Characteristics of cardiac surgery

a)Preoperative assessment (venous line, tests, fasting, prior bath):

Yes $\square$ No $\square$

Do you wish you had received information about this content?

Yes $\square$ No $\square$

b)Type of anesthesia and potential complications:

Yes $\square$ No $\square$

Do you wish you had received information about this content?

Yes $\square$ No

c)Potential risks or complications of surgery:

Yes $\square$ No

Do you wish you had received information about this content? Yes $\square$ No $\square$

d)Hospitalization in the unit of pediatric critical patients: Yes $\square$ No $\square$

Do you wish you had received information about this content? Yes $\square$ No $\square$

e)Physical appearance of the child after the surgery: Yes $\square$ No

Do you wish you had received information about this content? Yes $\square$ No 
TOPIC 3: Care after cardiac surgery

a)Routine care provided by the department (visiting hours, visits, standards): Yes $\square$ No $\square$

Do you wish you had received information about this content? Yes $\square$ No $\square$

b)Length of stay (days) in the unit of pediatric critical patients: Yes $\square$ No $\square$

Do you wish you had received information about this content? Yes $\square$ No $\square$

c)Presence of invasive devices (catheters, tubes, drainages, leads): Yes $\square$ No $\square$

Do you wish you had received information about this content? Yes $\square$ No $\square$

d)Skin care and surgical wound care:

Yes $\square$ No $\square$

Do you wish you had received information about this content? Yes $\square$ No $\square$

e)Opportunity to accompany your child and become involved in his/her care (feeding, hygiene, recreational activities): Yes $\square$ No $\square$

Do you wish you had received information about this content? Yes $\square$ No $\square$

TOPIC 4: Care after discharge

a)Return to daily living activities: Yes $\square$ No $\square$

Do you wish you had received information about this content? Yes $\square$ No $\square$

b)Measures to prevent growth problems: Yes $\square$ No $\square$

Do you wish you had received information about this content? Yes $\square$ No $\square$

c)Measures to prevent nutritional problems: Yes $\square$ No $\square$

Do you wish you had received information about this content? Yes $\square$ No $\square$

d)Measures to prevent respiratory conditions: Yes $\square$ No $\square$

Do you wish you had received information about this content? Yes $\square$ No $\square$

e)Measures to prevent cardiovascular conditions: Yes $\square$ No $\square$

Do you wish you had received information about this content? Yes $\square$ No $\square$

Please indicate if you received information and you wished you had received information about some other content not included in this list: 
ITEM 2: EDUCATORS

\section{a) Pediatrician:}

Yes $\square$ No $\square$

Do you wish you had received information from this health care provider?

b)Cardiologist:

Yes $\square$ No $\square$

Yes $\square$ No $\square$
Do you wish you had received information from this health care provider?
Yes $\square$ No $\square$

c)Nurse:

Yes $\square$ No

Do you wish you had received information from this health care provider?

Yes $\square$ No

\section{d)Nutritionist:}

Yes $\square$ No $\square$

Do you wish you had received information from this health care provider?

Yes $\square$ No $\square$

e)Physical therapist:

Yes $\square$ No $\square$

Do you wish you had received information from this health care provider?

Yes $\square$ No $\square$

f)Educational psychologist:

Yes $\square$ No

Do you wish you had received information from this health care provider?

g)Psychologist:

Yes $\square$ No $\square$

Do you wish you had received information from this health care provider?

Yes $\square$ No

Please indicate if you received information and you wished you had received information from other health care provider not included in this list:

\section{ITEM 3: TIME}

a)Upon admission to the UC Clinical Hospital:

Yes $\square$ No $\square$

Do you wish you had received information at this time?

Yes $\square$ No $\square$

\section{b)During hospitalization:}

Yes $\square$ No $\square$

Do you wish you had received information at this time?

Yes $\square$ No $\square$

c)Upon discharge or transfer to the referring hospital:

Yes $\square$ No

Do you wish you had received information at this time?

Yes $\square$ No

Please indicate if you received information and you wished you had received information at some other time not included in this list: 
ITEM 4: PLACE

a)In the child's room:

Yes $\square$ No $\square$

Do you wish you had received information in this place?

Yes $\square$ No $\square$

b)In a private room:

Yes $\square$ No $\square$

Do you wish you had received information in this place?

c)In the hall:

Yes $\square$ No $\square$

Do you wish you had received information in this place?

Yes $\square$ No

Please indicate if you received information and you wished you had received information in som other place not included in this list:

\section{ITEM 5: MEANS}

a)Oral information:

\section{Yes $\square$ No}

Do you wish you had received information by this means?

Yes $\square$ No $\square$

b)Educational brochures:

Yes $\square$ No

Do you wish you had received information by this means?

Yes $\square$ No $\square$

c)Group workshops:

Yes $\square$ No $\square$

Do you wish you had received information by this means?

Yes $\square$ No $\square$

d)Indirect methods (videos, slides, hospital tours, Internet):

Yes $\square$ No

Please, specify.

Do you wish you had received information by this means?

Yes $\square$ No $\square$

Please, specify.

Please indicate if you received information and you wished you had received information by sor other means not included in this list: 